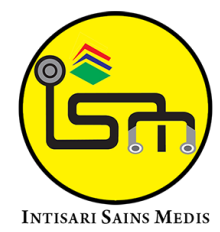

Published by Intisari Sains Medis

\title{
Hubungan konsentrasi serum C-Reactive Protein dan D-dimer dengan derajat keparahan dan mortalitas pasien COVID-19
}

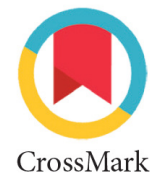

\author{
Kadek Surya Atmaja ${ }^{1 *}$, Anak Agung Gede Oka Suta Wicaksana ${ }^{2}$, \\ I Wayan Angga Suamerta Putra ${ }^{3}$, Wayan Wahyu Semara Putra ${ }^{4}$
}

'Intern of Pulmonology and Respiratory Medicine Department, Wangaya Regional General Hospital, Denpasar, Bali, Indonesia.

${ }^{2}$ Intern of Internal Medicine Department, Wangaya Regional General Hospital, Denpasar, Bali, Indonesia. ${ }^{3}$ Resident of Pulmonology and Respiratory Medicine Department, Sanglah General Hospital, Denpasar, Bali, Indonesia.

${ }^{4}$ Pulmonologist of Pulmonology and Respiratory Medicine Department, Wangaya Regional General Hospital, Denpasar, Bali, Indonesia.

\section{*Korespondensi:}

Kadek Surya Atmaja; Intern of Pulmonology and Respiratory Medicine Department, Wangaya Regional General Hospital, Denpasar, Bali, Indonesia; suratmaja89@gmail.com

\section{Diterima: 19-02-2021}

Disetujui: 24-07-2021

Diterbitkan: 31-08-2021

\section{ABSTRACT}

Background: Clinical features of COVID-19 are variably from asymptomatic, to severe symptoms including acute respiratory distress syndrome (ARDS), multiple organ failure, and death. A specific biomarker is needed to predict the possibility of COVID-19 patients fall into severe complications and disease severity. D-dimer and C-Reactive Protein (CRP) are biomarkers that are elevated in COVID-19 patients.

Method: This is an observational analytic study. The purpose of this research is to explore the correlation between D-dimer serum concentration and CRP with disease severity and mortality in hospitalized COVID-19 patients. This research used secondary data from a medical record with inclusion criteria patient more than 18 years old, confirmed COVID-19 by real-time Polymerase chain reaction (rt-PCR), that hospitalized in Wangaya General Hospital during July 2020 until December 2020.

Result: Statistical analysis show that there is

significant mean difference between D-dimer and CRP concentration based on COVID-19 disease severity ( $p$ $<0.001$ dan $p<0.001$ ). AUC value on ROC curve for CRP and D-dimer concentration in predict the mortality of COVID-19 patient are 0.88 ( $p<0.001,95 \%$ Cl: $0.829-$ $0.48)$ and $0.88(\mathrm{p}<0.001,95 \% \mathrm{Cl}=0.821-0.950)$ respectively. In this research, serum D-dimer with concentration more than $4,181 \mathrm{ng} / \mathrm{mL}$ statistically significant affect the mortality of COVID-19 patient $(O R=11.713 ; C l=1.620-84.682 ; p=0.015)$. CRP concentration statistically is not significant affect the mortality of COVID-19 patient.

Conclusion: There is a statistically mean difference in both D-dimer and CRP concentration based on COVID-19 disease severity. D-dimer concentration of more than $4,181 \mathrm{ng} / \mathrm{mL}$ significantly affects the COVID-19 mortality. CRP concentration is not correlated with COVID-19 mortality

Keywords: C-reactive Protein, D-dimer, COVID-19

Cite This Article: Atmaja, K.S., Wicaksana, A.A.G.O.S., Putra, I.W.A.S., Putra, W.W.S. 2021. Hubungan konsentrasi serum C-Reactive Protein dan D-dimer dengan derajat keparahan dan mortalitas pasien COVID-19. Intisari Sains Medis 12(2): 680-685. Dol: 10.15562/ism.v12i2.971

\section{ABSTRAK}

Latar Belakang: Fitur klinis pasien dengan COVID-19 bervariasi dari tanpa gejala maupun dengan gejala ringan hingga terjadinya acute respiratory distress syndrome (ARDS), gagal multi organ, dan kematian. Dibutuhkan suatu biomarker yang dapat digunakan dalam memprediksi kemungkinan pasien yang akan jatuh kedalam derajat penyakit maupun komplikasi yang berat. D-dimer dan C-Reactive Protein (CRP) merupakan biomarker yang diketahui meningkat pada pasien COVID-19.

Metode: Penelitian ini merupakan penelitian analitik observasional, yang bertujuan untuk mengetahui hubungan konsentrasi D-dimer serum dan CRP dengan derajat keparahan dan mortalitas pasien COVID-19 yang dirawat inap. Penelitian ini menggunakan data sekunder yang bersumber dari rekam medis dengan kriteria inklusi pasien usia diatas 18 tahun dengan diagnosis terkonfirmasi COVID-19 dengan real-time Polymerase chain reaction $(r t-P(R)$, yang dirawat inap di RSUD Wangaya Denpasar periode Juli 2020 hingga Desember 2020.

Hasil: Hasil uji statistik menunjukan terdapat perbedaan rerata konsentrasi D-dimer dan CRP berdasarkan derajat keparahan pasien COVID-19 yang 
bermakna secara statistik ( $p<0,001$ dan $p<0,001$ ). Nilai AUC kurva ROC konsentrasi CRP dan D-dimer dalam memprediksi mortalitas pasien secara berturut-turut didapatkan sebesar 0.88 ( $p<0,001,95 \%$ IK: 0,829 $-0,48$ ) dan 0.88 ( $p<0,001,95 \%$ IK: $0,821-0,950)$. D-dimer serum dengan konsentrasi diatas $4.181 \mathrm{ng} / \mathrm{mL}$ pada penelitian ini terbukti secara statistik bermakna mempengaruhi mortalitas pasien COVID-19 (OR OR 11,713; IK:1,620-84,682; $p=0,015)$. Konsentrasi (RP serum tidak terbukti secara statistik bermakna dalam mempengaruhi mortalitas pasien COVID-19.

Simpulan: Terdapat perbedaan rerata yang bermakna secara statistik konsentrasi serum D-dimer dan CRP berdasarkan derajat keparahan penyakit COVID-19. Konsentrasi serum D-dimer diatas $4.181 \mathrm{ng} / \mathrm{mL}$ terbukti mempengaruhi mortalitas pasien dengan COVID-19 secara bermakna. Konsentrasi CRP tidak berhubungan terhadap mortalitas pada pasien COVID-19.

Kata kunci: C-reactive Protein, D-dimer, COVID-19

Sitasi Artikel ini: Atmaja, K.S., Wicaksana, A.A.G.O.S., Putra, I.W.A.S., Putra, W.W.S. 2021. Hubungan konsentrasi serum C-Reactive Protein dan D-dimer dengan derajat keparahan dan mortalitas pasien COVID-19. Intisari Sains Medis 12(2): 680-685. D0I: 10.15562/ism.v12i2.971

\section{PENDAHULUAN}

Pada bulan Desember, tahun 2019 di Wuhan, Provinsi Hubei, Tiongkok, ditemukan kasus pneumonia berat dengan penyebab yang tidak diketahui. Pada tanggal 7 januari 2020, di identifikasi penyebab kasus pneumonia berat adalah Coronavirus yang memiliki > $70 \%$ kesamaan dengan virus Severe Acute Coronavirus (SARS-CoV). ${ }^{1}$ World Health Organization (WHO) kemudian menamakan penyakit tersebut sebagai Novel Viral Pneumonia "Coronavirus Disease 2019" (COVID-19), sedangkan virus penyebab penyakit tersebut dinamakan "Severe Acute Coronavirus-2" (SARS-CoV-2) oleh International Committee on Taxonomy of Viruses. ${ }^{2-5}$

Pasien COVID-19 diketahui tidak hanya mengalami manifestasi gangguan respirasi, beberapa penelitian telah melaporkan adanya gangguan koagulasi yang terjadi pada pasien COVID-19. Hal tersebut terjadi diakibatkan kondisi hiperinflamasi yang terjadi pada pasien COVID-19. Koagulopati yang terjadi pada pasien COVID-19 berhubungan dengan peningkatan mortalitas yang signifikan pada pasien tersebut. Aktivasi kaskade koagulasi dipicu oleh terjadinya respon hiperinflamasi pada pasien COVID-19. ${ }^{3}$

Hingga saat ini masih terdapat sedikit penelitian mengenai biomarker yang dapat digunakan dalam memprediksi tingkat keparahan maupun mortalitas pada pasien COVID-19. D-dimer merupakan sebuah biomarker koagulasi yang diketahui meningkat pada pasien
COVID-19. Selain itu, C-reactive protein (CRP) merupakan suatu biomarker inflamasi yang juga ditemukan meningkat pada pasien COVID-19. ${ }^{4}$ Penelitian ini bertujuan untuk mengetahui hubungan konsentrasi serum D-dimer dan CRP dengan derajat keparahan dan mortalitas pasien COVID-19 yang dirawat inap.

\section{METODE}

Penelitian ini merupakan penelitian analitik observasional menggunakan data sekunder yang bersumber dari rekam medis, dengan pengambilan sampel dilakukan dengan cara total sampling. Kriteria inklusi pada penelitian ini adalah pasien usia diatas 18 tahun dengan diagnosis terkonfirmasi COVID-19 dengan real-time Polymerase chain reaction $(r t-P C R)$, yang dirawat inap di RSUD Wangaya Denpasar periode Juli 2020 hingga Desember 2020 (No.070/193/ RSUDW/2021). Pasien terkonfirmasi COVID-19 dengan data rekam medis tidak lengkap di eksklusi dari penelitian ini.

Definisi operasional variabel dari D-dimer adalah konsentrasi D-dimer dalam plasma pasien terkonfirmasi COVID-19 yang diukur saat hari pertama pasien dirawat inap. Satuan untuk kadar D-dimer adalah $\mathrm{ng} / \mathrm{mL}$. C-reactive protein adalah konsentrasi $C$-reactive protein dalam plasma pasien terkonfirmasi COVID-19 yang diukur saat hari pertama pasien dirawat inap. Satuan untuk kadar C-reactive protein adalah $\mathrm{mg} / \mathrm{L}$. Derajat keparahan COVID-19 berdasarkan kriteria yang dikeluarkan oleh WHO yakni ringan, sedang, berat, dan kritis. Pada penelitian ini derajat keparahan dikelompokan menjadi 3 yaitu ringan, sedang, berat-kritis. Usia pada penelitian ini dikelompokan menjadi kelompok usia 18-59 tahun dan kelompok usia lebih dari 60 tahun. Gambaran foto rontgen dada pasien dikelompokkan berdasarkan lateralitas paru yang terdampak yakni normal, unilateral, serta bilateral. Morbiditas pada pasien adalah pasien terkonfirmasi COVID-19 dengan satu atau lebih penyakit, diantaranya diabetes mellitus, penyakit kardiovaskular, hipertensi, penyakit paru obstruktif kronis, dan penyakit ginjal kronis. Analisis data menggunakan program statistik SPSS $^{\curvearrowleft}$ 26. Dilakukan analisis deskriptif (univariate) dan studi komparasi (bivariate) menggunakan uji chi-square $p$ value $<0,01$ dianggap signifikan.

\section{HASIL PENELITIAN}

Pada penelitian ini sebanyak 223 pasien memenuhi kriteria inklusi, karakteristik subjek penelitian dapat dilihat pada Tabel 1. Mayoritas subjek pada penelitian ini berusia diatas 60 tahun yakni sebanyak 161 orang $(73 \%)$ sedangkan pasien usia 18 60 tahun pada penelitian ini didapatkan sebanyak 62 orang (27\%) (Tabel 1).

Mayoritas jenis kelamin pada subjek penelitian ini adalah laki-laki yaitu 125 $(56,1 \%)$. Berdasarkan derajat penyakit didapatkan pasien dengan sebanyak 50 (22.4\%) dengan derajat penyakit ringan, $120(53,8 \%)$ pasien dengan derajat 
penyakit sedang, dan $53(23,8)$ pasien dengan derajat penyakit berat-kritis. Pada penelitian ini didapatkan sebanyak $25(11,2 \%)$ pasien meninggal. Gambaran rontgen dada pasien yang dikelompokan berdasarkan lateralitas paru yang terdampak didapatkan gambaran normal $55(24,7 \%)$, infiltrat unilateral $28(12,6 \%)$, dan infiltrat bilateral pada 140 pasien $(62,8 \%)$. Pada penelitian ini didapatkan pasien dengan komorbiditas berupa: diabetes mellitus 28 (12,5\%), PPOK 5 (2,3\%), penyakit kardiovaskular 10 $(4,4 \%)$, penyakit hati kronis $4(1,7 \%)$, dan hipertensi 22 (9,9\%) (Tabel 1).

Tabel 1. Karakteristik dasar subjek penelitian

\begin{tabular}{|c|c|}
\hline Karakteristik & Jumlah \\
\hline \multicolumn{2}{|l|}{ Usia } \\
\hline 18-60 tahun & $62(27 \%)$ \\
\hline$>60$ tahun & $161(73 \%)$ \\
\hline \multicolumn{2}{|l|}{ Jenis kelamin (\%) } \\
\hline Laki-Laki & $125(56,1)$ \\
\hline Perempuan & $98(43,9)$ \\
\hline \multicolumn{2}{|l|}{ Derajat Penyakit (\%) } \\
\hline Ringan & $50(22.4)$ \\
\hline Sedang & $120(53,8)$ \\
\hline Berat-Kritis & $53(23,8)$ \\
\hline \multicolumn{2}{|l|}{ Mortalitas (\%) } \\
\hline Penyintas & $198(88,8)$ \\
\hline Meninggal & $25(11,2)$ \\
\hline \multicolumn{2}{|c|}{ Lateralitas Chest X-Ray (\%) } \\
\hline Normal & $55(24,7)$ \\
\hline Infiltrat Unilateral & $28(12,5)$ \\
\hline Infiltrat Bilateral & $140(62,8)$ \\
\hline \multicolumn{2}{|l|}{ Morbiditas } \\
\hline \multicolumn{2}{|l|}{ Diabetes Mellitus } \\
\hline Ya & $28(12,5)$ \\
\hline Tidak & $195(87,5)$ \\
\hline \multicolumn{2}{|l|}{ PPOK } \\
\hline $\mathrm{Ya}$ & $5(2.3)$ \\
\hline Tidak & $213(97,7)$ \\
\hline \multicolumn{2}{|c|}{ Penyakit Kardiovaskular } \\
\hline Ya & $10(4,4)$ \\
\hline Tidak & $213(96)$ \\
\hline \multicolumn{2}{|l|}{ Hipertensi } \\
\hline $\mathrm{Ya}$ & $22(9,9)$ \\
\hline Tidak & $201(90,1)$ \\
\hline \multicolumn{2}{|l|}{ Penyakit Ginjal Kronis } \\
\hline $\mathrm{Ya}$ & $12(5,4)$ \\
\hline Tidak & $211(94,6)$ \\
\hline
\end{tabular}

Terdapat perbedaan rerata konsentrasi CRP berdasarkan derajat keparahan COVID-19. Pasien dengan derajat penyakit berat-kritis memiliki rerata konsentrasi CRP serum tertinggi yaitu 133 $\mathrm{mg} / \mathrm{L}(34 \mathrm{mg} / \mathrm{L}-200 \mathrm{mg} / \mathrm{L}$ ) dibandingkan derajat ringan sebesar $8,52 \mathrm{mg} / \mathrm{L}(5 \mathrm{mg} / \mathrm{L}$ - $21 \mathrm{mg} / \mathrm{L}$ ) ataupun derajat sedang sebesar $35,12 \mathrm{mg} / \mathrm{L}(10 \mathrm{mg} / \mathrm{L}-97 \mathrm{mg} / \mathrm{L})$ (Tabel 2).

Pada uji normalitas data menggunakan uji Kolmogorov-Smirnov, didapatkan

\section{Tabel 2. Tabel hubungan antara derajat penyakit COVID-19 dengan kadar CRP}

\begin{tabular}{llc}
$\begin{array}{c}\text { Derajat } \\
\text { Penyakit }\end{array}$ & $\begin{array}{c}\text { Kadar C-Reactive } \\
\text { Protein Serum }\end{array}$ & $\begin{array}{c}\text { Nilai } \\
\text { p }\end{array}$ \\
\hline \multicolumn{3}{c}{$\begin{array}{c}\text { rerata (minimum- } \\
\text { maksimum) }\end{array}$} \\
\hline Ringan & $8,32(5-21)$ & $\mathrm{p}<$ \\
Sedang & $35,12(10-97)$ & 0,01 \\
Berat-Kritis & $133(34-200)$ & \\
& &
\end{tabular}

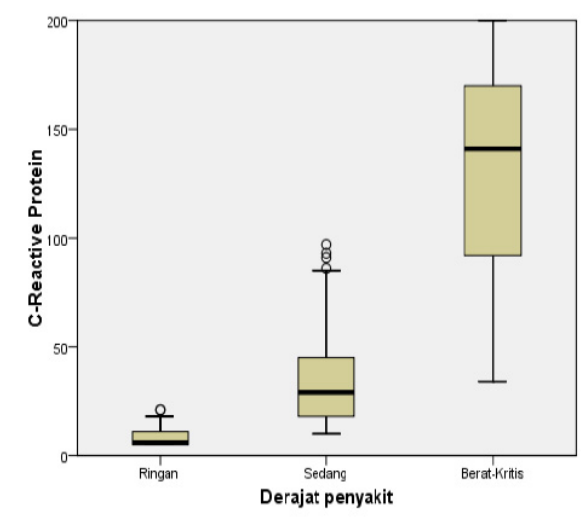

Gambar 1. Grafik perbandingan rerata CRP menurut derajat penyakit COVID-19 (p $<0,001)$.

Tabel 3. Tabel hubungan antara derajat penyakit COVID-19 dengan kadar CRP

\begin{tabular}{ccc}
\hline Derajat Penyakit & $\begin{array}{c}\text { Kadar } \mathbf{D} \text {-dimer Serum } \\
\text { rerata (minimum-maksimum) }\end{array}$ & Nilai $\mathbf{p}$ \\
\hline Ringan & $366(107-785)$ & $\mathrm{p}<0,001$ \\
Sedang & $1.390(302-4.143)$ & \\
Berat-Kritis & $7.851(1.139-16.944)$ & \\
\hline
\end{tabular}

sebaran data konsentrasi CRP dengan distribusi tidak normal, sehingga digunakan uji Kruskal-Wallis untuk menguji beda rerata konsentrasi CRP berdasarkan derajat keparahan COVID-19. Rerata konsentrasi CRP serum berdasarkan derajat keparahan didapatkan perbedaan yang bermakna secara statistik $(p<0,001)$. Grafik rerata konsentrasi CRP berdasarkan tingkat keparahan COVID-19 dapat dilihat pada Gambar 1.

Perbandingan rerata konsentrasi serum D-dimer berdasarkan derajat keparahan COVID-19 dapat dilihat pada Gambar 2. Pasien dengan derajat penyakit berat-kritis memiliki rerata konsentrasi serum D-dimer tertinggi yaitu 7.851 $\mathrm{ng} / \mathrm{mL}(1.139 \mathrm{ng} / \mathrm{mL}-16.944 \mathrm{ng} / \mathrm{mL})$ dibandingkan derajat ringan sebesar 366 $(107 \mathrm{ng} / \mathrm{mL}-785 \mathrm{ng} / \mathrm{mL})$ dan derajat sedang sebesar $1.390 \mathrm{ng} / \mathrm{mL}(302 \mathrm{ng} / \mathrm{mL}$ - $4.143 \mathrm{ng} / \mathrm{mL}$ ).

Pada uji normalitas data menggunakan uji Kolmogorov-Smirnov, sebaran data konsentrasi D-dimer didapatkan dengan distribusi tidak normal, sehingga

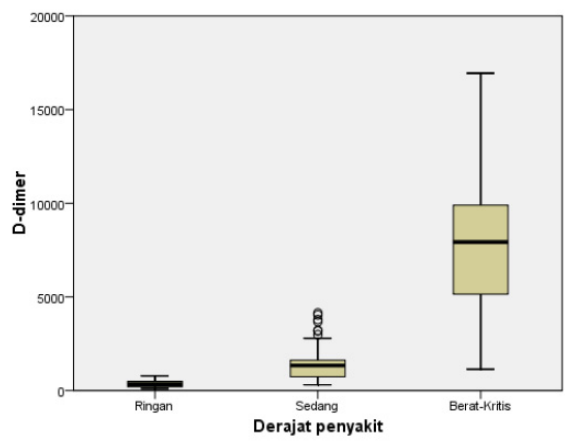

Gambar 2. Grafik perbandingan rerata D-Dimer menurut derajat penyakit COVID-19 (p < 0,001). 
digunakan uji beda rerata menggunakan uji Kruskal wallis. Rerata konsentrasi D-dimer serum berdasarkan derajat keparahan didapatkan perbedaan yang bermakna secara statistik ( $\mathrm{p}<0.001$ ) (Tabel 3).

Pada penelitian ini dilakukan penentuan cut off CRP dan D-dimer dalam memprediksi mortalitas COVID-19 dengan menggunakan kurva ROC. Kurva ROC CRP terhadap mortalitas pasien COVID-19 dapat dilihat pada Gambar 3. Pada kurva ROC menunjukan sensitivitas dengan nilai Area Under Curve (AUC) sebesar 0,88 ( $\mathrm{p}<0,001,95 \%$ CI: $0,829-$ 0,48 ). Pada penelitian ini nilai cut off CRP terbaik dalam memprediksi mortalitas pada pasien COVID-19 adalah sebesar

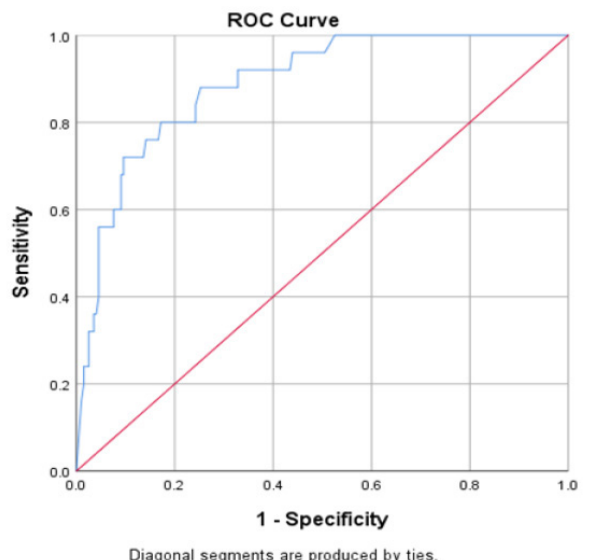

Gambar 3. Kurva ROC C-Reactive Protein terhadap mortalitas pasien COVID-19

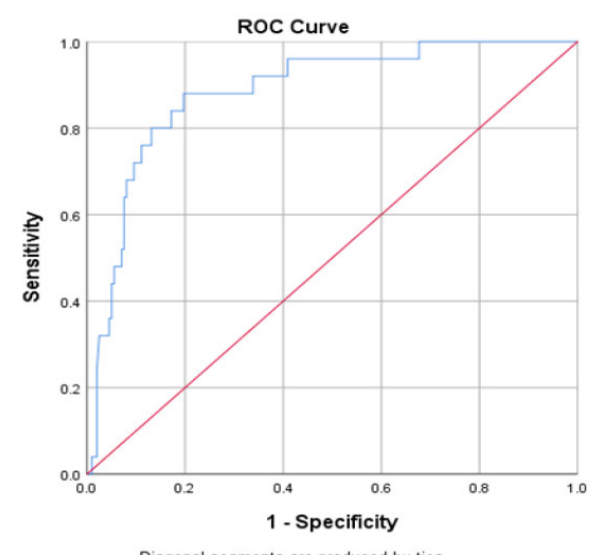

Gambar 4. Kurva ROC D-dimer terhadap mortalitas pasien COVID-19
72,50 $\mathrm{mg} / \mathrm{L}$ dengan sensitivitas sebesar 0,800 dan spesifitas sebesar 0,828 . Kurva ROC D-dimer terhadap mortalitas pasien COVID-19 dapat dilihat pada Gambar 4. Nilai AUC kurva ROC D-dimer terhadap mortalitas pasien COVID-19 didapatkan sebesar 0,88 ( $\mathrm{p}<0,001,95 \%$ CI: 0,821 - 0,950). Nilai Cut off D-dimer terbaik dalam memprediksi mortalitas pada pasien COVID-19 didapatkan sebesar $4.181 \mathrm{ng} / \mathrm{ml}$. Secara statistik nilai AUC sebesar $88 \%$ tergolong cukup.

Pada penelitian ini untuk mengetahui hubungan D-dimer dan CRP terhadap mortalitas pasien COVID-19 serta pengaruh variabel perancu berupa umur, jenis kelamin, serta komorbiditas pasien (diabetes, PPOK, penyakit kardiovaskular, penyakit hati kronis, dan hipertensi) dilakukan analisis regresi logistik yaitu binary logistic model. CRP dikategorikan ulang berdasarkan cut off yang didapatkan dalam kurva ROC menjadi $\leq 72,50 \mathrm{mg} / \mathrm{L}$ dan $\geq 72,51 \mathrm{mg} / \mathrm{L}$. D-dimer dikategorikan ulang berdasarkan cut off yang didapatkan dalam kurva ROC menjadi $\leq 4.181 \mathrm{ng} /$ $\mathrm{ml} \geq 4.182 \mathrm{ng} / \mathrm{ml}$. Usia dikategorikan berdasarkan usia $\leq 59$ tahun dan $\geq 60$ tahun, jenis kelamin dikategorikan berdasarkan jenis kelamin laki-laki dan perempuan, sedangkan komorbiditas dikategorikan berdasarkan terdapat komorbiditas dan tidak terdapat komorbiditas. Hasil analisis binary logistic regression dapat dilihat pada Tabel 4

Pada analisis binary logistic model Tabel 4, serum D-dimer dengan konsentrasi diatas 4,181 ng/mL terbukti secara bermakna mempengaruhi

Tabel 4. Hasil analisis binary logistic regression CRP, D-dimer, dan variabel perancu terhadap mortalitas pasien COVID-19

\begin{tabular}{lcccc}
\hline \multicolumn{1}{c}{ Variabel } & B & Exp (B) & IK 95\% & Nilai p \\
\hline Umur & 1,019 & 2,771 & $0,826-9,290$ & 0,099 \\
Jenis Kelamin & $-0,417$ & 0,659 & $0,193-2,255$ & 0,507 \\
D-dimer & 2,461 & 11,713 & $1,620-84,682$ & 0,015 \\
CRP & 1,290 & 3,633 & $0,467-28,265$ & 0,218 \\
Diabetes melitus & $-0,815$ & 0,443 & $0,89-2,214$ & 0,443 \\
PPOK & 1,1 & 3,004 & $0,244-36,928$ & 0,390 \\
Penyakit kardiovaskular & $-0,879$ & 0,443 & $0,039-4,401$ & 0,465 \\
Penyakit ginjal kronis & $-1,380$ & 0,268 & $0,21-3,331$ & 0,268 \\
Hipertensi & 1.745 & 5,728 & $1,028-31,867$ & 0,046 \\
\hline
\end{tabular}

mortalitas pasien COVID-19 (OR 11,713; IK:1,620-84,682; $\mathrm{p}=0,015)$. Pada analisis tersebut juga didapatkan pasien dengan komorbiditas yakni pasien dengan hipertensi jika dibandingkan dengan pasien yang tidak memiliki hipertensi terbukti secara statistik bermakna mempengaruhi mortalitas pasien COVID-19 (OR 5,728; IK: 1,028-31,867; $\mathrm{p}=0,046)$. Konsentrasi CRP dan variabel perancu lain pada penelitian ini tidak didapatkan mempengaruhi mortalitas pasien COVID-19 secara bermakna.

\section{PEMBAHASAN}

Fitur klinis pasien dengan COVID-19 bervariasi dari asimptomatis hingga terjadinya acute respiratory distress (ARDS) dan gagal multi organ. Penentuan kategori derajat keparahan COVID-19 sangat diperlukan untuk diagnosis dan memastikan tatalaksana serta mencegah komplikasi yang dapat terjadi pada pasien. Diperlukan suatu biomarker yang dapat digunakan untuk mengkategorikan pasien berdasarkan kelompok derajat keparahan dan untuk memprediksi kemungkinan pasien yang akan jatuh kedalam derajat penyakit maupun komplikasi yang berat.

CRP yang merupakan suatu protein homopentamerik merupakan suatu biomarker inflamasi yang diketahui meningkat pada pasien dengan COVID-19. CRP diketahui meningkat sebagai respon terhadap luka, infeksi, maupun inflamasi. Sebagai protein fase akut, konsentrasi CRP serum meningkat setidaknya $25 \%$ selama proses inflamasi 
berlangsung. CRP disintesis oleh sel hepar bergantung Interleukin (IL)-6. CRP berperan sebagai aktivasi komplemen C1q sehingga memicu terjadinya opsonisasi patogen. Konsentrasi tertinggi didapatkan pada infeksi bakteri yang dapat meningkat hingga 1.000 kali lipat. Ketika rangsangan inflamasi berhenti, CRP menurun secara eksponensial dalam 18-20 jam. Rerata kadar CRP serum normal pada ras kaukasian sehat didapatkan sebesar 0,8 $\mathrm{mg} / \mathrm{L}$. ${ }^{6}$

Penelitian yang dilakukan oleh Chaochao dkk mendapatkan konsentrasi CRP pada pasien COVID-19 derajat berat lebih tinggi dibandingkan pasien COVID-19 dengan derajat ringan maupun sedang. Pada penelitian tersebut juga didapatkan AUC kurva ROC CRP yang diperiksa pada saat pasien pertama kali dirawat inap dalam memprediksi mortalitas pasien COVID-19 memiliki nilai sebesar 0,87 (95\% CI $0,10-100$ ). CRP pada penelitian tersebut meningkat secara bermakna pada fase awal bahkan sebelum ditemukan abnormalitas gambaran pencitraan. ${ }^{7}$ Pada penelitian ini juga didapatkan pasien terkonfirmasi COVID-19 dengan derajat keparahan berat-kritis memiliki rerata nilai CRP tertinggi $(133 \mathrm{mg} / \mathrm{L}, \mathrm{p}<0,001)$. Kurva ROC CRP dalam memprediksi mortalitas pasien COVID-19 pada penelitian ini juga menunjukan sensitivitas dengan nilai AUC sebesar 0,88 ( $\mathrm{p}<0.001,95 \%$ CI: $0,829-0,948)$.

D-dimer merupakan molekul yang terbentuk dari hasil degradasi fibrin pada fibrinolisis. Peningkatan konsentrasi D-dimer pada serum mengindikasikan terjadi suatu proses koagulasi intravaskular. ${ }^{8}$ Penelitian yang dilakukan oleh Mertz dkk dengan melibatkan 120 subjek penelitian, mendapatkan peningkatan D-dimer pada $63,3 \%$ pasien. Pada penelitian tersebut didapatkan peningkatan konsentrasi D-dimer berkorelasi positif dengan umur, lama rawat, keterlibatan paru, konsentrasi fibrinogen, dan hasil hitung neutrofil. ${ }^{9}$

Penelitian lain yang dilakukan oleh Yao dkk menunjukkan peningkatan D-dimer pada $74,6 \%$ subjek penelitian (185/248). Pada penelitian tersebut juga didapatkan peningkatan D-dimer meningkat secara bermakna dengan peningkatan derajat keparahan COVID-19 ( $\mathrm{p}=0,000)$. Pada penelitian tersebut didapatkan AUC kurva ROC D-dimer dalam memprediksi mortalitas pasien COVID-19 sebesar 0,85 (95\% IK: 0,77 - 0,92). ${ }^{10}$ Sejalan dengan kedua penelitian tersebut, pada penelitian ini didapatkan perbedaan rerata yang bermakna antara konsentrasi D-dimer terhadap derajat penyakit COVID-19. Pasien dengan derajat penyakit beratkritis memiliki rerata konsentrasi $\mathrm{D}$-dimer serum tertinggi yaitu $7.851 \mathrm{ng} / \mathrm{mL}(1.139$ $\mathrm{ng} / \mathrm{mL}-16.944 \mathrm{ng} / \mathrm{mL}$ ). Nilai AUC kurva ROC D-dimer terhadap mortalitas pasien COVID-19 pada penelitian ini didapatkan sebesar 0,88 ( $\mathrm{p}<0,001,95 \%$ IK: 0,821 $0,950)$.

Penelitian meta-analisis dilakukan oleh Zheng dkk terkait meneliti faktor risiko yang berhubungan dengan mortalitas pasien COVID-19 dengan total 3.027 subjek pasien, didapatkan beberapa faktor resiko yang bermakna mempengaruhi mortalitas pasien COVID-19. Usia $>65$ tahun $(\mathrm{OR}=6,06,95 \%$ IK $(3,98-9,22), \mathrm{P}$ $<0,00001)$. Pasien dengan komorbiditas juga diketahui meningkatkan mortalitas seperti diabetes $(\mathrm{OR}=3,68,95 \%$ IK $(2,68$ - 5,03), $\mathrm{P}<0,00001)$, hipertensi (OR $2,72,95 \%$ IK $(1,60-4,64), P=0,0002)$, penyakit kardiovaskular $(\mathrm{OR}=5,19,95 \%$ IK $(3,25-8,29), P<0,00001)$, penyakit saluran pernapasan $(\mathrm{OR}=5,15,95 \%$ IK $(2,51$ - 10,57), $\mathrm{P}<0,00001) .{ }^{11}$ Hasil berbeda didapatkan pada penelitian ini, pada penelitian ini didapatkan hanya komorbiditas berupa hipertensi yang didapatkan terbukti secara bermakna mempengaruhi mortalitas pasien COVID-19, pasien dengan hipertensi dibandingkan pasien dengan tanpa hipertensi terbukti secara bermakna mempengaruhi mortalitas COVID-19 pada penelitian ini (OR 5,728, 95\% IK $(1,028-31,867), p=0,046)$.

$\mathrm{D}$-dimer serum dengan konsentrasi diatas $4.181 \mathrm{ng} / \mathrm{mL}$ pada penelitian ini terbukti secara statistik bermakna mempengaruhi mortalitas pasien COVID-19 (OR 11,713; 95\% IK $(1,620$ - 84,682), $\quad p=0,015)$. Hasil ini juga didukung oleh penelitian yang dilakukan oleh Soni dkk. ${ }^{12}$ Pada penelitian tersebut dilakukan penelitian terhadap 448 subjek, didapatkan kadar D-dimer $\geq 2.010 \mathrm{ng} /$ $\mathrm{mL}$ terbukti secara statistik bermakna sebagai prediktor kematian pasien dengan COVID-19 (P < 0,01; hazard ratio (HR) $3,165,95 \% \operatorname{IK}(2,013-4,977) .{ }^{12}$

Pada penelitian ini didapatkan konsentrasi CRP serum tidak terbukti secara statistik bermakna dalam mempengaruhi mortalitas pasien COVID-19. Hasil ini berbeda dengan penelitian yang dilakukan oleh Huang dkk, dimana pada penelitian tersebut didapatkanpeningkatanCRPberhubungan dengan luaran yang buruk pada pasien COVID-19 (risk ratio (RR) 1,84, 96\% IK $(1,45-2,33), \mathrm{p}<0,001) \cdot{ }^{13}$ Penelitian lain yang dilakukan oleh Tjahyadi dkk dengan meneliti CRP terhadap mortalitas pasien COVID-19 dinilai dari derajat hipoksemia pasien, didapatkan konsentrasi CRP tidak berkorelasi dengan derajat hipoksemia pada pasien COVID-19. ${ }^{14}$

\section{SIMPULAN}

Rerata konsentrasi CRP dan D-dimer terhadap derajat penyakit COVID-19 berbeda bermakna secara statistik. Konsentrasi D-dimer serum diatas 4.181 $\mathrm{ng} / \mathrm{mL}$ mempengaruhi mortalitas pasien dengan COVID-19 secara bermakna. Secara keseluruhan, konsentrasi CRP tidak berhubungan terhadap mortalitas pada pasien COVID-19.

\section{KONFLIK KEPENTINGAN}

Penulis menyatakan tidak terdapat konflik kepentingan terkait publikasi dari artikel ini.

\section{PENDANAAN}

Penelitian ini tidak mendapat dana hibah dari pemerintah maupun lembaga swasta lainnya.

\section{KONTRIBUSI PENULIS}

Seluruh penulis berkontribusi terhadap penelitian ini baik dari perencanaan proposal penelitian, pencarian data, analisis data penelitian, hingga interpretasi dan penyusunan naskah publikasi.

\section{DAFTAR PUSTAKA}

1. Singhal T. A Review of Coronavirus Disease-2019 (COVID-19). Indian J Pediatr. 2020;87(4):281-286. doi:10.1007/s12098-02003263-6. 
2. Ponti G, Maccaferri M, Ruini C, Tomasi A, Ozben T. Biomarkers associated with COVID-19 disease progression. Crit Rev Clin Lab Sci. 2020;57(6):389-399. doi:10.1080/1040 8363.2020.1770685.

3. Zhang L, Guo H. Biomarkers of COVID-19 and technologies to combat SARS-CoV-2. Adv Biomark Sci Technol. 2020;2:1-23. doi:10.1016/j. abst.2020.08.001.

4. Willim, H.A., Hardigaloeh, A.T., Supit, A.I., Handriyani. 2020. Koagulopati pada Coronavirus Disease-2019 (COVID-19): Tinjauan pustaka. Intisari Sains Medis 11(3): 749-756. DOI: 10.15562/ism.v11i3.766.

5. World Health Organization. Therapeutics and COVID-19: living guideline. WHO. int. 2021 [cited 7 February 2021]. Available from: https:// www.who.int/publications/i/item/therapeuticsand-covid-19-living-guideline.

6. Sproston NR, Ashworth JJ. Role of C-Reactive Protein at Sites of Inflammation and Infection. Front Immunol. 2018;9:754. Published 2018 Apr 13. doi: 10.3389/fimmu.2018.00754.
7. Tan C, Huang Y, Shi F, et al. C-reactive protein correlates with computed tomographic findings and predicts severe COVID-19 early. J Med Virol. 2020;92(7):856-862. doi:10.1002/ jmv.25871.

8. Johnson E, Schell J, Rodgers G. The D-dimer assay. American Journal of Hematology. 2019;94:833-839. doi: 10.1002/ajh.25482.

9. Ozen M, Yilmaz A, Cakmak V, et al. D-Dimer as a potential biomarker for disease severity in COVID-19. Am J Emerg Med. 2021;40:55-59. doi:10.1016/j.ajem.2020.12.023.

10. Yao, Y., Cao, J., Wang, Q. et al. D-dimer as a biomarker for disease severity and mortality in COVID-19 patients: a case control study. $j$ intensive care 8, 49 (2020). https://doi. org/10.1186/s40560-020-00466-Z.

11. Zheng $\mathrm{Z}$, Peng $\mathrm{F}, \mathrm{Xu} \mathrm{B}$, et al. Risk factors of critical \& mortal COVID-19 cases: A systematic literature review and meta-analysis. $J$ Infect. 2020;81(2):e16-e25. doi:10.1016/j. jinf.2020.04.021
12. Soni M, Gopalakrishnan R, Vaishya R, Prabu P. $\mathrm{D}$-dimer level is a useful predictor for mortality in patients with COVID-19: Analysis of 483 cases. Diabetes Metab Syndr. 2020;14(6):22452249. doi:10.1016/j.dsx.2020.11.007.

13. Huang I, Pranata R, Lim MA, Oehadian A, Alisjahbana B. C-reactive protein, procalcitonin, D-dimer, and ferritin in severe coronavirus disease-2019: a meta-analysis. Ther Adv Respir Dis. 2020;14:1753466620937175. doi:10.1177/1753466620937175.

14. Tjahyadi R, Astuti T, Listyoko A. COVID-19 :Correlation Between CRP and $\mathrm{LDH}$ to Disease Severity and Mortality In Hospitalized COVID-19 Patients. Medica Hospitalia : Journal of Clinical Medicine. 2020;7(1A):144149. doi: $10.36408 / \mathrm{mhjcm} . v 7 i 1 \mathrm{~A} .467$

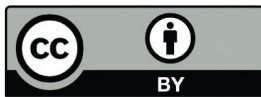

This work is licensed under a Creative Commons Attribution 